\title{
Article
}

\section{Over-use of short-acting inhalers for uncontrolled asthma}

Davies, Janice Anne

Available at http://clok.uclan.ac.uk/21249/

Davies, Janice Anne (2017) Over-use of short-acting inhalers for uncontrolled asthma. Nurse Prescribing, 15 (3). pp. 114-115. ISSN 2052-2924

It is advisable to refer to the publisher's version if you intend to cite from the work. 10.12968/npre.2017.15.3.114

For more information about UCLan's research in this area go to http://www.uclan.ac.uk/researchgroups/ and search for <name of research Group>.

For information about Research generally at UCLan please go to http://www.uclan.ac.uk/research/

All outputs in CLoK are protected by Intellectual Property Rights law, including Copyright law. Copyright, IPR and Moral Rights for the works on this site are retained by the individual authors and/or other copyright owners. Terms and conditions for use of this material are defined in the policies page.

\section{CLoK}

Central Lancashire online Knowledge www.clok.uclan.ac.uk

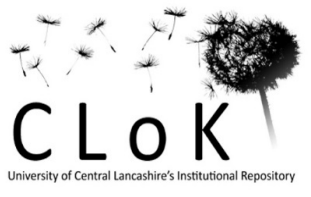


Why asthma still kills (Royal College of Physicians, 2015) is the National Review of Asthma Deaths' (NRAD) first national investigation of asthma deaths in the UK and the largest study worldwide to date. The primary aim was to understand the circumstances surrounding asthma deaths in order to identify avoidable factors and make recommendations to improve care and reduce the number of deaths.

Some of the recommendations involve prescribing and medicines use. One of these specifically states "All asthma patients who have been prescribed more than 12 short-acting reliever inhalers in the previous 12 months should be invited for urgent review of their asthma control, with the aim of improving their asthma through education and change of treatment if required."

The reason for this is that over-use of short acting relievers can be an indication of uncontrolled asthma. An additional concern due to over-use can be explained by the pharmacology of shortacting relievers. These medicines, such as salbutamol and terbutaline, are beta- 2 receptor agonists see BNF (BMA\&RPS, 2016). Over use of agonist drugs leads to "down-regulation" of receptors and the outcome of this to the patient is that when needed in emergency the therapeutic effect may be insufficient to relieve their symptoms. Also, over-use of medicines can lead to side effects (eg palpitations or anxiety), and is a waste of NHS resources.

Imagine a scenario where you are working with your practice pharmacist to address this matter.

The pharmacist has searched the practice computer system and identified a list of 29 patients who have received more than 12 prescriptions for Short acting beta-agonists (SABAs) in the last 12 months. You have 1450 patients on the asthma register.

\section{Question 1}

What percentage of asthma patients need to be invited for an urgent review? $2 \%$

Most of these patients are receiving repeat prescriptions for "salbutamol 100microgram per metered dose 200 dose cfc-free inhaler".

\section{Question 2}

If a patient has used 12 of these in a 12 month period, how many doses per day does this indicate they have used?

a. Less than 2 puffs

b. 3 to 5 puffs

c. 6 to 8 puffs

\section{Question 3}

In well controlled asthma SABAs should not be needed more than twice per week. Assume your patient uses 2 puffs twice a week.

How long should one salbutamol 200 dose inhaler last?
a. Less than 4 months
b. 5-10 months
c. More than 11 months

\section{Question 4}


You notice that some patients are being issued with two salbutamol 200 dose inhalers per month. How many doses per day does this indicate that they are using?
a. 6-10 puffs
b. $11-15$ puffs
c. $16-20$ puffs

Many patients with asthma also require an inhaled corticosteroid (ICS). The Medicines and Healthcare Product Regulatory Agency recommends that beclomethasone-containing metered dose inhalers (MDIs) are prescribed by brand because the available products are not interchangeable. Two brands are available. Qvar is an ICS with an ultra-fine particle size. This means that the prescribed dose should be HALF of the standard formulation Clenil MDI.

\section{Question 5}

Imagine your local formulary recommends Qvar as the first line ICS of choice. Calculate the Qvar dose that is equivalent to these doses of Clenil (you may need to use your BNF if you are not familiar with the available Qvar presentations):

a. Clenil 100micrograms per dose, 2 puffs twice a day Qvar 50 micrograms per dose, 2 puffs twice a day

b. Clenil 200micrograms per dose, 2 puffs twice a day Qvar 100 micrograms per dose, 2 puffs twice a day

Some asthma patients additionally require a Long Acting Beta Agonist (LABA) alongside their ICS. Imagine the following LABA/ICS combination products are available to you:

Fostair 100/6 MDI.

DuoResp 160/4.5 Spiromax

Symbicort 200/6 Turbohaler

\section{Question 6}

Use the BNF to find out the constituents of each of these products then state which of the following ICS/LABA combinations is equipotent:

a. Fostair 100/6 1 puff twice a day | Symbicort 200/6 1 puff twice a day | Duoresp 160/4.5 1 puff twice a day

b. Fostair 100/6 2 puffs twice daily | Symbicort 200/6 1 puff twice a day | Duoresp 160/4.5 1 puff twice a day

c. Fostair 100/6 2 puffs twice a day | Symbicort 200/6 1 puff twice a day | Duoresp 160/4.5 2 puffs twice a day 